Aktualnie finalizowane sq badania nad dziejami edukacji rolniczej na Warmii i Mazurach w XX wieku oraz analizą porównawcza szkolnictwa rolniczego w Polsce i we Francji. Obecnie, z uwagi na krótki jeszcze okres funkcjonowania Zakładu Pedagogiki Historyczno-Porównawczej, wypracowywany jest profil jego działalności naukowej. Zakłada się zorientowanie badań zwłaszcza na studia nad dziejami systemów edukacji zawodowej, rozpatrywanej w kontekście istotnych uwarunkowań społeczno-ekonomicznych oraz $w$ ujęciu komparatystycznym.

W omawianych zakładach badania $\mathrm{z}$ zakresu historii wychowania prowadzi trzech profesorów nadzwyczajnych, jeden doktor habilitowany, trzech doktorów, dwóch magistrów oraz trzech doktorantów. Dotychczasowa aktywność naukowa pracowników obu zakładów zaowocowała łączną liczbą około 300 publikacji. Wśród nich jest kilkanaście opracowań zwartych (naukowych i dydaktycznych) oraz ponad 200 artykułów i rozpraw opublikowanych w czasopismach i publikacjach zbiorowych. Wyniki badań prezentowane były też na różnych konferencjach naukowych w kraju i za granica.

Andrzej Gqsiorowski Alicja Kicowska

\title{
Irena Sondecka - obrończyni polskości z obwodu tarnopolskiego na Ukrainie (z dziejów tajnej oświaty na sowieckiej Ukrainie po II wojnie światowej)
}

Wielu Polaków na Ukrainie w okresie międzywojennym i powojennym przeżyło tragedie osobiste, ale dramatem wszystkich Polaków na tej ziemi było ciągłe i metodyczne unicestwianie ich kultury, oświaty, tradycji narodowych i religii. Problemy te poruszano już w publicystyce i literaturze naukowej, ale wiele zapewne będzie się jeszcze o tych zagadnieniach pisać. W niniejszym tekście postaram się tylko wyrazić osobiste refleksje na ten temat, jak również przytoczyć dane dotyczące patriotycznej działalności nauczycielki z Krzemieńca - Ireny Sondeckiej, działającej na rzecz zachowania polskości w tym mieście w okresie powojennym.

Żeby w pehni ocenić znaczenie tej działalności postaram się krótko przeanalizować problemy związane $\mathrm{z}$ historią szkolnictwa polskiego na Ukrainie sowieckiej.

Na podstawie danych spisu ludności (1970) na Ukrainie zamieszkiwało 295,1 tys. Polaków ${ }^{1}$. Diaspora polska wśród tzw. mniejszości narodowych zajmowała (po Rosjanach, Białorusinach i Żydach) pod względem liczebności czwarte miejsce. Należy sądzić, że od tamtego czasu zmniejszyła się diaspora żydowska z powodu wyjazdów dużej ilości przedstawicieli tej narodowości do krajów zachodnich. Liczba przedstawicieli innych narodowości (nie biorąc pod uwage zmian społeczno-politycznych po rozpadzie ZSRR), praktycznie nie zmieniła się. Odnośnie diaspory polskiej można stwierdzić, że zwiększyła się ona znacznie pod wpływem wzmożenia działalności ruchów narodowościowych pod koniec lat 80-tych, działalnosici organizacji polonijnych, odrodzenia świadomości narodowej Polaków. Zniknął też strach przed deportacjami znanymi $z$ okresu przedwojennego i powojennego, kiedy realnie grozily ,wywózki" za polskie pochodzenie. Uważam, że stan ilościowy mniejszości polskiej w obecnej sytuacji na Ukrainie pod wpływem m.in. wymienionych czynników znacznie wzrósł i przekracza 400 tys. osób.

W latach 70-tych, kiedy liczbę Polaków na Ukrainie oficjalnie szacowano na 300 tysięcy, 
w tej sowieckiej republice były tylko dwie polskie szkoły (obie we Lwowie).

Autor tego tekstu wyjeżdżał służbowo do Kijowa i Lwowa na podstawie listu Ministerstwa Edukacji ZSRR do władz oświatowych na Ukrainie, w związku z przygotowywaniem artykułu o szkolnictwie polskim w ZSRR dla „Kwartalnika Pedagogicznego"2 . W ciagu kilku dni zwiedzałem te szkoły, zapoznałem sie z ich kierownictwem, ze stanem wychowania i nauczania dzieci. W porównaniu do Litwy (gdzie wtedy pracowałem) bylem zdziwiony stosunkiem przedstawicieli władz oświatowych miasta do tych szkół w których $\mathrm{z}$ ich punktu widzenia „wychowuje się obcy element".

Szkoda mi było tych dzieci ze szkoły podstawowej im. Feliksa Dzierżyńskiego, która była oficjalnie udekorowana politycznymi hasłami na czerwonym tle o przyjaźni narodów Związku Sowieckiego, o kierowniczej roli KPZR, z wyrazami wdzięczności za szczęśliwe dzieciństwo itd. Podobna sytuacja panowała w średniej szkole im. Wandy Wasilewskiej. Ogólna liczba uczniów tych szkół nie przekraczała 450-500 osób. W szkołach tych brakowało podręczników w języku polskim do wielu przedmiotów, albo nie było żadnych podręczników. Brakowało też nauczycieli mówiących po polsku.

Wtedy przykre wrażenie zrobił na mnie również Lwów. Dworzec kolejowy (z zewnątrz) był dosłownie obwieszony ogromnymi portretami członków Biura Politycznego KPZR. Taka "gotowość ideologiczna" związana była z wydarzeniami w Polsce (strajki lat 80-tych). Można tylko współczuć ludności polskiej Lwowa w tym okresie i dzieciom polskim Ukrainy, którym władza zezwoliła na funkcjonowanie tylko tych szkół. Jednocześnie trudno było wyobrazić sobie, że w kraju, który występował jako „wzór dla wszystkich narodów świata” w rozwiazywaniu problemów socjalnych, politycznych i narodowościowych tysięcy dzieci polskich pozbawiono prawa (realnego, bo takie prawo konstytucyjne istniało ${ }^{3}$ ) do nauki szkolnej w jezzyku ojczystym.

Oczywiście, że wbrew takiej polityce, $\mathrm{z}$ wielkim trudem $\mathrm{i}$ strachem przed prześladowaniami, aresztami i możliwymi przesiedleniami tworzyło się i poszerzało wychowanie i nau- czanie jezzyka polskiego w rodzinach i szkołach tajnych.

Jednym $\mathrm{z}$ takich przykładów może być mała szkółka tajna w Krzemieńcu Wołyńskim, prowadzona przez panią Irenę Sondecką. Pani Irena, absolwentka UJ okresu międzywojennego, zaczęła uczyć w latach pięćdziesiątych religii i języka polskiego $w$ swoim domku, stojącym w pobliżu byłego Liceum Krzemienieckiego i kościoła, gdzie był ochrzczony Juliusz Słowacki. Jako biolog nie miała doświadczenia w nauczaniu początkowym i w związku z tym musiała samodzielnie uzupełnić swoją wiedzę $w$ tej dziedzinie pedagogiki.

Ucząc dzieci czytać i pisać po polsku doszła do wniosku, że nauka ta powinna opierać się na wykorzystaniu wiedzy uczniów z języka ukrainskiego $\mathrm{i}$ wiedzy o swoim mieście. Chodziło również o to, żeby uczniowie byli nieco starsi i umieli dotrzymać tajemnicy na temat działalności szkółki, która nie miała prawa istnieć. Grupa początkująca (każda z tych grup liczyła 5-8 osób) musiała opanować "kurs wstępny" i najpierw „doskonaliła" swój język polski z panią nauczycielką, uczyła się podstaw religii, słuchała bajek i wierszyków, a niekiedy uczyła się ich na pamięć. Prawdziwa nauka języka zaczynała się od klasy I-szej oficjalnej, czyli od nauki alfabetu cyrylicznego $w$ tej szkole $i$ równolegle nauczania alfabetu polskiego w szkole Pani Ireny. Takie litery jak A, K, O, I, T, M, E, w alfabecie ukrainskim i polskim mają nie tylko identyczną grafikę, ale i odpowiadają tym samym dźwiękom. Litery H, C, P, B, podobnie sie pisze, ale sq̨ obrazem graficznym innych głosek niż $w$ języku polskim. Sporo liter różni się diametralnie. Są to: Z, Z, Y, D, F, G, L, L, N, ich opanowanie wymagało specjalnej pracy. Sporo trudności było z podręcznikami. Te, które Pani Irena miała $\mathrm{z}$ okresu międzywojennego, nie uwzględniały metodyki stosowanej w tej szkole - wykorzystywania już posiadanej przez uczniów wiedzy z języka ukraińskiego, brakowało materiału o rodzinnym i dobrze znanym dzieciom Krzemieńcu i okolicach. Potrzebny był whasny elementarz oparty na tych zasadach.

Już w latach pięćdziesiątych Pani Irena zaczęła pracować nad takim elementarzem i po wielu jego wersjach i udoskonaleniach został on „wydany". Wydany nie w drukarni, 
a ręcznie napisany w jednym egzemplarzu dla potrzeb wlasnych. Nazywał się „Elementarz krzemieniecki" i składał się z dwóch części, licząc 92 strony; miał ilustracje i napisy w dwóch zeszytach uczniowskich do rysowania ${ }^{4}$. Wartość „Elementarza krzemienieckiego” nie byłaby w petni oceniona bez nawet krótkiej analizy jego strony wychowawczej, co dla dzieci polskich tych terenów miało szczególne znaczenie.

Większość tekstów opierało się na dobrze znanym dzieciom z Krzemieńca materiale miejscowym Autorka wspominała „srebrzystą Ikwę", „dolinę Ikwy”, „górę królowej Bony”, Juliusza Slowackiego, Liceum Krzemienieckie $i$ in.

Z 42 stron części II - 8 stron poświęcono Juliuszowi Słowackiemu.

„Niechaj mnie Zośka o wiersze nie prosi,

Bo kiedy Zośka do Ojczyzny wróci

To każdy kwiatek powie wiersze Zosi

Każda jej gwiazdka piosenkę zanuci

Nim kwiat przekwitnie, nim gwiazdeczka zleci Słuchaj - bo to są najlepsi poeci".

Cytując wiersze J. Słowackiego autorka przypominała dzieciom, że poeta urodził się w Krzemieńcu, że na cmentarzu tunickim pochowana zostaka matka poety. Obok tego tekstu umieszczono rysunek ze skałami zwanymi jego imieniem.

Na dwóch ostatnich stronach poświęconych kościołowi przy Liceum Krzemienieckim (z rysunkiem), informuje się uczniów, że w ich mieście była stynna uczelnia - szkoła polska zwana Liceum Krzemienieckim, w której uczył języka polskiego ojciec Juliusza Słowackiego - Euzebiusz Stowacki.

Wiele tekstów elementarza zawierało treści dotyczące kultury osobistej i higieny.

"Ala ma jeszcze szczotkę do włosów i małą szczoteczke do czyszczenia zębów", "Nie jedz na ulicy i nie pluj", „Julia myje podłoge i gotuje" $i$ in.

Kilka stron elementarza poświẹcono religii, nie bacząc na to, że w tym czasie kiedy go pisano za religijne wychowanie, tym bardziej w szkole tajnej i jeszcze do tego polskiej, groziła kara ze strony whadz.

Dla przykładu przytaczam jeden $\mathrm{z}$ takich tekstów:

„Dzyń, dzyń - to dzwonia dzwonki od sań, to jadą z Wesołówki na sumę. Na wieży dzwoni duży dzwon i woła na nabożeństwo. A ksiądz już czeka w konfesjonale".

W czerwcu 1990 r. miałem spotkanie z $\mathrm{Pa}$ nią Ireną $i$ jej uczniami w Krzemieńcu $w$ jej domku. Dziewczynki i chłopcy w wieku 8-13 lat byli dumni z tego, że ucza się w tej „szkole" (w której na liście wychowanków wpisano okoto 300 „absolwentów”), że mieszkają w takim słynnym ośrodku kultury polskiej, gdzie Polacy z dziada pradziada nie tylko mieszkali, ale i wnosili wielki wkład w rozwój kultury polskiej, i ogólnoludzkiej. Jak widać „Elementarz krzemieniecki" nie tylko służył nauce języka ojczystego, zapoznając jednocześnie z zasadami pisowni polskiej, ale również wychowywal, budził serca dzieci ku miłości do swojej historii i narodu.

Po likwidacji ZSRR dużo zmieniło się w życiu Polaków na byłych kresach wschodnich. Od 1990 r. dzięki fundacji im. T. Ganiewicza $i$ in. Polacy Ukrainy i Białorusi otrzymali sporo książek i podręczników polskich, w tym elementarz autorstwa H. Metery "Czytam po polsku”, co zlikwidowało poprzedni głód podrecznikowy na tych terenach. „Elementarz krzemieniecki” nadal nie traci swojego znaczenia i nie tylko jako podręcznik dydaktyczny „szkółki" Pani Ireny Sondeckiej, ale jako symbol nieumierającej polskości i wielkiego czynu patriotycznego.

Wiek i dolegliwości zdrowotne utrudniały ostatnio działalność tej patriotce. Jednak to co zrobiła $w$ ciagu poprzednich dziesięcioleci zasługuje na to, żeby imię tej działaczki oświaty tajnej okresu powojennego na Ukrainie sowieckiej i autorki "Elementarza krzemienieckiego" było wpisane na trwałe do dziejów wychowania polskiego i krzewienia patriotyzmu polskiego.

Michal Dobrynin 8. 537 .

1 Wielka encyklopedia radziecka, wyd. 3, t. 26,

2 M. Dobrynin, Elementarz krzemieniecki. „Kwartalnik Pedagogiczny”, 1991, nr 4, s. 154-156.

${ }^{3}$ Konst ytucja ZSRR, 1987, t. 1, 8. 36.

4 I. Sondecka, Elementarz krzemieniecki (archiwum autora), 8. 154-156. 